\title{
PEMBELAJARAN MENYIMAK TEKS ANEKDOT KELAS X KECANTIKAN SMKN 4 BANJARMASIN
}

\section{LEARNING LISTENS TO THE ANECDOTAL TEXT CLASS X KECANTIKAN SMKN 4 BANJARMASIN}

\author{
Nur Hafifah; Moh.Fatah Yasin; Ahsani Taqwiem \\ Program Studi Pendidikan Bahasa dan Sastra Indonesia \\ FKIP Universitas Lambung Mangkurat \\ unuy0897@gmail.com
}

\begin{abstract}
Abstrak
Tujuan penelitian ini untuk mendeskripsikan perencanaan pelaksanaan pembelajaran, proses pelaksanaan pembelajaran, dan evaluasi pembelajaran menyimak teks anekdot pada kelas $\mathrm{X}$ Kecantikan SMKN 4 Banjarmasin. Penelitian ini menggunakan pendekatan kualitatif. Metode penelitian ini yaitu dengan mengumpulkan data melalui observasi, wawancara, dan dokumentasi. Hasil penelitian ini mendsikripsikan pelaksanaan pembelajaran menyimak teks anekdot di sekolah. Dalam pembelajaran pelaksanaan ada tiga tahap yaitu perencanaan, pelaksanaan, dan evaluasi. Kegiatan perencanaan RPP sesuai dengan kurikulum 2013, guru sudah membuat RPP yang terdiri dari indikator, materi, kegiatan pembelajaran, penilaian, media, bahan dan sumber belajar beberapa komponen yang tidak dimasukkan oleh guru yaitu alokasi waktu dan metode yang digunakan. Guru juga tidak memasukkan tujuan pembelajaran. Pelaksanaan terdiri dari tiga kegiatan yaitu pendahuluan, kegiatan inti (pendekatan saintifik), dan kegiatan penutup. Tahap evaluasi guru berdasarkan presentasi di depan kelas dan keaktifan dalam pembelajaran dan untuk penilaian dilihat dari hasil unjuk kerja kelompok.
\end{abstract}

Kata Kunci: pembelajaran, menyimak, anekdot.

\begin{abstract}
The purpose of this study is to describe the planning of learning implementation, the process of implementing learning, and evaluating learning listening to anecdotal texts in class $X$ Beauty of SMK 4 Banjarmasin. This study uses a qualitative approach. This research method is by collecting data through observation, interviews, and documentation. The results of this study describe the implementation of learning listening to anecdotal texts in schools. In implementation learning there are three stages, namely planning, implementation and evaluation. RPP planning activities are in accordance with the 2013 curriculum, teachers have made lesson plans consisting of indicators, materials, learning activities, assessment, media, materials and learning resources that some components are not included by the teacher, namely the allocation of time and methods used. The teacher also does not include learning objectives. The implementation consists of three activities, namely introduction, core activities (scientific approach), and closing activities. The teacher evaluation phase is based on the percentage in front of the class and activeness in learning and for assessment seen from the results of group performance.
\end{abstract}

Keywords: learning, listening, anecdotes. 


\section{Pendahuluan}

Menyimak merupakan satu dari empat keterampilan bahasa Indonesia. Menyimak adalah kegiatan di mana tidak hanya mendengar tetapi memperhatikan secara mendalam untuk mendapatkan informasi yang diinginkan secara baik. Anekdot adalah cerita atau teks lucu yang di dalamnya mengandung sebuah makna atau kritikan. Untuk menemukan makna yang tersirat tersebut harus mampu memahami struktur dan isinya secara baik. Sebagian peserta didik saat ini belum mampu memahami struktur dan kaidahnya. Banyak faktor yang mempengaruhi hal tersebut. Diantaranya tidak konsentrasi saat guru menjelaskan, kurang menyukai mata pelajaran, dan metode pembelajaran, selama ini guru hanya menggunakan metode ceramah dalam menyampaikan materi sehingga peserta didik merasa bosan dan tidak menyimak penyampaian guru. Teks anekdot dipilih sebagai objek penelitian karena teks ini ada di kurikulum 2013 pada KD 3.6 kelas X. Selain mengandung unsur lucu dan mengesankan, anekdot juga memiliki pesan moral di dalamnya yang bisa diterapkan dalam kehidupan. peserta didik diharapkan mampu berpikir kritis untuk mengetahui makna apa yang ada di dalam teks tersebut. Berdasarkan hal ini, pembelajaran teks anekdot dalam kurikulum 2013 cukup menarik untuk diteliti. Kemampuan peserta didik menentukan struktur dan menemukan makna tersirat menjadi tolak ukur keberhasilan pembelajaran. Guru sebagai fasilitator tidak hanya bisa menyampaikan pembelajaran di depan kelas tetapi guru harus mampu merancang bagaimana proses pembelajaran yang nantinya akan dilaksanakan sehingga keberhasilan pembelajaran dapat dicapai dengan maksimal. Berdasarkan hal tersebut, peneliti ingin mengetahui bagaimana proses pelaksanaan pembelajaran yang dilakukan oleh guru kelas X Kecantikan SMKN 4 Banjarmasin.

Penelitian ini dilaksanakan di SMKN 4 Banjarmasin. SMKN 4 Banjarmasin sering memenangkan LKS (Lomba Kejuruan Sekolah). Artinya, SMKN 4 Banjarmasin termasuk sekolah yang unggul di bidang kejuruan diantara sekolah kejuruan lainnya. Namun, prestasi nonakademik belumlah menjamin kualitas peserta didiknya. Penelitian ini dilakukan untuk mengetahui apakah kualitas akademik peserta didik SMKN 4 Banjarmasin sebanding dengan prestasi kejuruannya.

Fokus dalam penelitian ini adalah pembelajaran menyimak teks anekdot. Melalui pembelajaran menyimak teks anekdot dapat diketahui sejauh mana peserta didik memahami dan menyerap 
informasi dalam pembelajaran teks anekdot.

\section{Metode Penelitian}

\section{Jenis Penelitian}

Pendekatan pada penelitian ini, yaitu menggunakan pendekatan deskriptif kualitatif. Penelitian ini bertujuan untuk mendiskripsikan apa yang saat ini berlaku. Terdapat upaya mendiskirpsikan, menganalisis, mencatat dan menginterpretasikan kondisi yang terjadi atau ada. data yang didapat berupa hasil pengamatan dan jawaban dari wawancara bersama guru .

\section{Waktu dan Tempat Penelitian}

Peneliti melaksanakan penelitian ini di kelas X Kecantikan SMKN 4 Banjarmasin yang diambil hari Selasa, 27 November 2018.

\section{Subjek dan Objek Penelitain}

Subjek pada penelitian ini yaitu guru yang mengajar mata pembelajaran Bahasa Indonesia. Objeknya adalah pelaksanaan pembelajaran menyimak teks anekdot.

\section{Data dan Sumber data}

Data penelitian ini adalah hasil pengamatan dan jawaban dari wawancara bersama guru. Sumber data didapat dari kelas X Kecantikan SMKN 4 Banjarmasin dari kegiatan pengamatan dan wawancara serta rekaman video. Karena keterbatasan memory kamera, video yang didapat tidak penuh selama dua jam pembelajaran.

\section{Teknik Pegumpulan Data}

Peneliti melakukan pengamatan dengan tidak berperanserta dan pengamatan terbuka, artinya keberadaan pengamat diketahui oleh subjek. Peneliti mengamati pembelajaran yang sedang berlangsung sambil mencatat hal-hal yang didapatkan. Kemudian peneliti melaksanakan wawancara. Wawancara dilakukan untuk memperoleh informasi yang diharapkan. Pada saat wawancara, guru tidak bersedia untuk direkam.

\section{Analisis Data}

Peneliti melakukan pengumpulan data yang diperoleh dari hasil pengamatan dan wawancara kemudian dicatat dan dikategorikan. Dicatat secara alami tanpa adanya pendapat. Selanjutnya dilakukan reduksi data, data diseleksi dan disederhanakan. Lalu melakukan penyajian data dan langkah terakhir yaitu penarikan kesimpulan.

\section{Hasil dan Pembahasan}

Berikut hasil pengamatan peneliti saat pembelajaran berlangsung di kelas $\mathrm{X}$ Kecantikan dan pengamatan dari dokumen (RPP). 


\section{Rencana Pelaksanaan Pembelajaran}

RPP dari guru sudah untuk empat kali pertemuan, tetapi untuk penelitian ini, peneliti meneliti pada pertemuan ketiga, yang membahas tentang struktur teks anekdot. Bagian-bagian yang ada di dalam RPP yang direncanakan oleh guru adalah a) Indikator pencapaian, indikator yang dirumuskan oleh guru hanya ada satu, yaitu mengidentifikasi struktur dan kebahasan teks anekdot. Tujuan tidak dituliskan di RPP, dari hasil wawancara tujuan pembelajaran pertemuan ketiga ini adalah agar peserta didik paham dan mampu mengidentifikasi stuktur teks anekdot. Dari hasil pengamatan, guru dan peserta didik berupaya mencapai tujuan pembelajaran. b) Materi pembelajaran, Materi yang diajarkan guru pada pertemuan ketiga dengan KD 3.6 yaitu struktur teks anekdot yang meliputi abstraksi, orientasi, krisis, reaksi, dan koda. Materi yang diajarkan sudah sesuai dengan RPP, Guru menjelaskan mengenai struktur teks anekdot dengan baik, tetapi tidak menjelaskan lebih dalam mengenai kebahasaannya, hanya fokus pada struktur teks anekdot. c) Model pembelajaran, model yang digunakan adalah Cooperative Learning. Berdasarkan hasil pengamatan dan wawancara, guru menggunakan metode ceramah, diskusi dan penugasan. Pada RPP, guru tidak mencantumkan metode yang hendak digunakan. Tetapi, guru mencantumkan model apa yang dipakai saat pembelajaran. Guru menggunakan metode dan model ini karena lumayan efektif digunakan di siang hari. Metode ceramah digunakan pada saat guru menjelaskan struktur teks anekdot. Diskusi dan penugasan digunakan ketika guru meminta peserta didik berdiskusi bersama kelompoknya masing-masing untuk menganalisis struktur dua teks anekdot yang dibagikan, hasil kerja nantinya akan dikumpulkan. d) langkahlangkah pembelajaran yaitu pendahuluan, kegiatan inti, dan penutup. Dalam pembelajaran guru sudah menggunakan langkah-langkah yang sesuai dengan RPP pada kegiatan pendahuluan dan kegiatan inti. Guru juga sudah menggunakan pendekatan saintifik di kegiatan inti. Guru melakukan pendekatan atau langkahlangkah pembelajaran yang sesuai dengan kurikulum 2013. Tetapi, pada kegiatan pendahuluan dan penutup ada langkah yang dilewatkan oleh guru. e) Media, bahan dan sumber pembelajaran yaitu buku LKS dan buku teks Bahasa Indonesia serta teks anekdot yang dibagikan. Guru menggunakan papan tulis dan teks anekdot yang dibagikan sendiri oleh guru. Papan tulis untuk mencatatkan materi yang akan diajarkan. Teks anekdot sebagai bahan yang akan dianalisis peserta didik untuk mengukur pemahaman peserta didik. 
Media ini dinilai lumayan efektif oleh guru. Dalam pembelajaran guru hanya bersumber pada guru dan buku, yaitu buku LKS dan buku teks kelas X. Buku LKS yang digunakan yaitu LKS Bahasa Indonesia Kelas X SMA/MA/SMK/MAK Semester 1 Kurikulum 2013 Edisi Revisi dan buku teks Bahasa Indonesia Kelas X SMA/MA/SMK/MAK Kementrian Pendidikan dan Kebudayaan Republik Indonesia 2015 Edisi Revisi 2016. f) Penilaian yang digunakan untuk pertemuan ketiga adalah unjuk kerja. Berdasarkan hasil wawancara, evaluasi pembelajaran dilakukan ketika presentasi. Guru memastikan pemahaman materi peserta didik saat presentasi dan tanya jawab. Untuk penilaian guru hanya menggunakan unjuk kerja, hasil kerja kelompok yang nantinya akan menjadi penilaian pembelajaran.

Dari hasil pengamatan, komponen yang ada pada RPP yang dibuat guru terdiri dari materi, model pembelajaran, kompetensi dan indikator. Ada beberapa komponen yang tidak dimasukkan oleh guru yaitu alokasi waktu dan metode yang digunakan. Guru juga tidak memasukkan tujuan pembelajaran.

\section{Pelaksanaan Pembelajaran}

Kegiatan

pelaksanaan

pembelajaran dimulai dengan kegiatan pendahuluan, guru memasuki ruang kelas, setelah duduk di kursi, guru kemudian mengecek kehadiran peserta didik dengan memanggil nama mereka satu persatu, dikarenakan pembelajaran dilaksanakan pada siang hari, maka tidak ada kegiatan berdoa bersama, karena berdoa hanya dilakukan di pagi hari saat pembelajaran mata pelajaran pertama, dilanjutkan dengan melakukan apersepsi yaitu mengajukan pertanyaan yang diajarkan pada pertemuan sebelumnya, setelahnya guru menyampaikan garis besar materi yang akan dibahas. Kegiatan selanjutnya memasuki kegiatan inti, Pada tahap ini, jika dilihat dari hasil pengamatan semua kegiatan inti yang ada di RPP sudah terlaksana. Tetapi guru hanya menjelaskan mengenai strukturnya saja tanpa membahas mengenai kebahasaan lebih dalam. Dari hasil pengamatan dan wawancara guru menggunakan pendekatan saintifik. Guru kemudian membagi peserta didik menjadi beberapa kelompok diskusi. Setiap kelompok mendapatkan dua teks anekdot yang akan di tentukan strukturnya yaitu, abstraksi, orientasi, krisis, reaksi, dan koda. setelah menentukan struktur, peserta didik diminta untuk mempresentasikan hasil kerjanya. Pada tahap ini, di kegiatan inti terjadi tahap menyimak dan pascasimak. Tahap menyimak adalah kegiatan di mana peserta didik menyimak sedangkan pascasimak adalah kegiatan yang dilakukan peserta 
didik sesudah menyimak. Tahap menyimak terjadi ketika guru menyampaikan materi, saat menyimak kelompok lain mempresentasikan hasil kerjanya, dan tanggapan. Tahap pascasimak terjadi saat mereka mempresentasikan dan mengumpulkan hasil kerjanya.

Dari hasil pengamatan dan wawancara, saat guru menjelaskan materi rata-rata peserta didik memperhatikan dan menyimak. Tetapi, pada beberapa kegiatan ada kendala yang juga berhubungan dengan kegiatan menyimak pembelajaran teks anekdot kendala tersebut yaitu:

1) Kegiatan diskusi tidak kondusif karena berisik,

2) saat presentasi dan saat kelompok lain memberi tanggapan banyak peserta didik tidak menyimak atau memperhatikan,

3) saat maju, satu dari anggota kelompok membacakan hasil kerja kelompoknya, ada anggota kelompok yang tidak menyimak temannya yang membacakan,

4) tidak semua kelompok maju mempresentasikan hasil kerjanya karena keterbatasan waktu pembelajaran.

Pada kegiatan inti, langkah-langkah sudah sesuai. Tetapi, ada beberapa kegiatan yang sudah disusun sebelumnya tidak terlaksana. Seperti pada kegiatan pendahuluan, satu langkah yang tidak terlaksana adalah kegiatan motivasi, dan pada kegiatan penutup ketiga langkah yang sudah direncanakan tidak terlaksana. Dalam melaksanakan pembelajaran, guru sudah melakukan prosedur pembelajaran menyimak. Prasimak terjadi pada kegiatan pendahuluan dan di kegiatan inti terjadi proses menyimak yaitu saat guru menjelaskan materi dan saat kelompok mempresentasikan hasil kerjanya. Menyimak ada dua jenis, yakni: menyimak ekstensif dan menyimak intensif. Jenis menyimak saat pembelajaran adalah menyimak intensif, dimana untuk memahami materi peserta didik harus menyimak dengan bersungguh-sungguh untuk dapat memahami dengan baik. Sedangkan pascasimak terjadi saat peserta didik mengerjakan tugas dan mengumpulkannya. Terakhir yaitu kegiatan penutup, berdasarkan hasil pengamatan, guru langsung menutup pembelajaran dengan menyampaikan bahwa hasil kerja kelompok mereka harus dikumpulkan nanti kemudian guru mengucapkan salam tanpa melakukan kegiatan merangkum hasil pembelajaran bersama. Guru tidak melakukan refleksi dan tidak menyampaikan materi yang akan dibahas di pertemuan selanjutnya. 
Evaluasi Pembelajaran

Berdasarkan hasil wawancara, evaluasi pembelajaran dilakukan ketika presentasi. Guru memastikan pemahaman materi peserta didik saat presentasi dan tanya jawab. Untuk penilaian guru hanya menggunakan unjuk kerja, hasil kerja kelompok yang nantinya akan menjadi penilaian pembelajaran. Guru menilai hanya dari hasil unjuk kerja kelompok yaitu menetukan struktur teks anekdot dari dua teks yang dibagikan oleh guru. Jadi, dapat disimpulkan bahwa pada pertemuan ketiga ini guru tidak mengevaluasi kompotensi sikap dan pengetahuan.

\section{Simpulan}

Berdasarkan hasil dan pembahasan penelitian terhadap pembelajaran menyimak teks anekdot di kelas $\mathrm{X}$ Kecantikan SMKN 4 Banjarmasin, dapat disimpulkan sebagai berikut.

A. Rencana Pelaksanaan Pembelajaran Guru sudah membuat RPP yang terdiri dari indikator, materi, kegiatan pembelajaran, penilaian, media, bahan dan sumber belajar.

1. Tujuan pembelajaran tidak dicantumkan, hanya ada satu indikator.
2. Materi pembelajaran mengikuti silabus tahun lalu. Materi yang diajarkan untuk KD 3.6 yaitu struktur teks anekdot tanpa membahas kebahasaan teks anekdot lebih dalam.

3. Model pembelajaran yang digunakan guru pada pembelajaran ini adalah Cooperative Learning. Metode yang digunakan yaitu diskusi kelompok, ceramah dan penugasan.

4. Langkah-langkah

Langkah pembelajaran yang di laksanakan guru terdiri dari kegiatan pendahuluan, kegiatan inti, dan kegiatan penutup.

5. Media yang digunakan yaitu LKS, buku teks, papan tulis, dan teks anekdot yang dibagikan.

6. Penilaian berupa unjuk kerja.

B. Pelaksanaan Pembelajaran

Pelaksanaan pembelajaran yang diterapkan oleh guru terdiri dari kegiatan pendahuluan, kegiatan inti (menggunakan pendekatan saintifik dan kegiatan penutup. 
1. Kegiatan Pendahuluan

Guru sudah melaksanakan tiga langkah kegiatan pendahuluan yang ada di RPP. Berdasakan hasil pengamatan langkah yang tidak dilaksanakan oleh guru yaitu menjelaskan manfaat materi ajar (motivasi). Disini guru sudah melakukan tahap prasimak, yaitu pada kegiatan apersepsi.

2. Kegiatan Inti

Guru menggunakan pendekatan sainfitik. Ada enam langkah kegiatan inti yang direncanakan, keenam langkah tersebut sudah sesuai dengan pelaksanaan pembelajarannya. Pada kegiatan ini terjadi tahap menyimak dan pascasimak. Tetapi, pada beberapa kegiatan ada kendala yang juga berhubungan dengan kegiatan menyimak pembelajaran teks anekdot

\section{Kegiatan Penutup}

Ada tiga langkah kegiatan penutup. Tetapi, guru langsung menutup pembelajaran dengan menyampaikan bahwa hasil kerja kelompok mereka harus dikumpul nanti kemudian mengucapkan salam.
C. Evaluasi Pembelajaran

Guru memperhatikan jalannya presentasi untuk mengukur pemahaman peserta didik dan untuk penilaian guru menggunakan unjuk kerja sesuai yang dituliskan di RPP. Guru tidak menggunakan penilaian autentik.

\section{Saran}

Berdasarkan hasil penelitian yang didapat, saran dari peneliti adalah sebagai berikut.

\section{Bagi Guru}

Guru diharapkan mampu menyiapkan dengan baik pembelajaran sebelum kegiatan dimulai, agar proses pembelajaran dapat berjalan optimal dan mampu meningkatkan lagi kualitas dan kreativitas mengajar. Dapat memperhitungkan waktu sangat penting dan memilih metode pembelajaran yang efisien.

2. Bagi Peserta Didik

Peserta didik kelas X Kecantikan SMKN 4 Banjarmasin diharapkan lebih memperhatikan pembelajaran dan memotivasi diri untuk terus belajar dan menghargai guru.

\section{Bagi Sekolah}

Sekolah sudah memfasilitasi kebutuhan dan kreativitas peserta didik. Sekolah harus lebih memberi dorongan 
dan memotivasi siswa dalam kegiatan

menyimak.

\section{Daftar Pustaka}

Abidin, Yunus. 2015. Pembelajaran Bahasa Berbasis Pendidikan Karakter. Bandung: Refika Aditama.

Hijriyah, Umi. 2016. Menyimak Strategi dan Implikasinya Dalam Kemahiran Berbahasa Indonesia. Lampung: Pusat Penelitian dan pengabdian Masyarakat IAIN Raden Intan Lampung.

Indrawati, Dewi, Bahasa Indonesia Kelas X SMA/SMK/MAK.

Istianah, Emy Lestari. 2015. Pembelajaran Keterampilan Menulis Teks Anekdot di Kelas X SMA Negeri 1 Sewon Bantul DIY. Yogyakarta: Universitas Negeri Yogyakarta.

Kurniawan, Heru. 2015. Pembelajaran Kreatif Bahasa Indonesia (Kurikulum 2013). Jakarta: Prenada Media Grup.

Lousy, Purnamasari dkk. 2015. Pembelajaran Menyimak Legenda Pada Siswa SMA. Pontianak: Program Studi Pendidikan Bahasa dan Sastra Indonesia FKIP Untan.

Mahsun. 2018. Teks dalam Pembelajaran Bahasa Indonesia Kurikulum 2013. Banjarmasin: Rajawalipers.

Moleong, Lexy J. 2009. Metodologi Penelitian Kualitatif. Bandung: PT. Remaja Rosdakarya.
Prastowo, Andi. 2017. Menyusun Rencana Pelaksanaan Pembelajaran (RPP) Tematik Terpadu. Jakarta:Predana Media Group.

Rosdawita. 2013. Pembelajaran Menyimak Berbasis Pendekatan Kontekstual. Jambi: FKIP Universitas Jambi.

Rusman. 2017. Belajar \& Pembelajaran Berorientasi Standar Proses Pendidikan. Jakarta: Prenada Media Group.

Sanjaya, Wina. 2015. Pembelajaran dalam Implementasi Kurikulum Berbasis Kompetensi. Jakarta: Prenada Media Group.

Soewandi, Slamet dkk. 2000. Strategi Pembelajaran Bahasa dan Sastra Indonesia di Sekolah : Berdasarkan Pendekatan Komunikatif. Yogyakarta: Universitas Sanata Dharma.

Tarigan, Henry Guntur. 1994, Menyimak Sebagai Suatu Keterampilan Berbahasa. Bandung: Angkasa.

Kencana, Lia. 2016. "PENINGKATAN KEMAMPUAN TEKS ANEKDOT DENGAN METODE PEMBELAJARAN, PENEMUAN SISWA KELAS X MIPA 2 SMAN 3 KOTA BENGKULU". Diksa: Vol.2 No.2 (2016). Publikasi Daring. 